Revue belge de géographie

$4 \mid 2018$

Transformations of urban space after the fall of Socialism

\title{
Post-Soviet single-industry cities in northern Russia: movement towards sustainable development
}

A case study of Kirovsk

Les villes mono-industrielles post-soviétiques du nord de la Russie : vers un

développement durable (étude de cas à Kirosvk)

Diana Dushkova and Tatyana Krasovskaya

\section{(2) OpenEdition}

Journals

Electronic version

URL: http://journals.openedition.org/belgeo/27427

DOI: $10.4000 /$ belgeo. 27427

ISSN: 2294-9135

Publisher:

National Committee of Geography of Belgium, Société Royale Belge de Géographie

Electronic reference

Diana Dushkova and Tatyana Krasovskaya, « Post-Soviet single-industry cities in northern Russia: movement towards sustainable development », Belgeo [Online], 4 | 2018, Online since 25 September 2018, connection on 10 October 2020. URL : http://journals.openedition.org/belgeo/27427 ; DOI : https://doi.org/10.4000/belgeo.27427

This text was automatically generated on 10 October 2020.

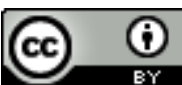

Belgeo est mis à disposition selon les termes de la licence Creative Commons Attribution 4.0 International. 


\title{
Post-Soviet single-industry cities in northern Russia: movement towards sustainable development
}

\author{
A case study of Kirovsk \\ Les villes mono-industrielles post-soviétiques du nord de la Russie : vers un \\ développement durable (étude de cas à Kirosvk)
}

Diana Dushkova and Tatyana Krasovskaya

The results presented here are a part of long-term investigations in the framework of several scientific projects: "Ecological buffer territories as an element of modern nature management structure at the Russian North" (N 15-05-02017), "Ecological-cultural role of territories of traditional nature use for sustainable development of the Russian Arctic" (N 15-06-02279), "Detection and mapping of potential nature management conflicts during perspective economic development of the Russian Arctic zone" (N 18-05-00335) and "Mathematical-cartographic assessment of medico-ecological situation in cities of European Russia by using the integrated ecological characteristics" (N 18-05-00236) funded by the Russian Foundation for Basic Research.

\section{Introduction}

1 The sustainable development of urban territories is broadly discussed nowadays (Dale et al., 2018; Fondahl, Wilson, 2017; Hassan, Lee, 2015; UN, 2016). The UN conference in 2015 adopted the Sustainable Development Goals for the period 2016-2030. Goal 11: "Make cities and human settlements inclusive, safe, resilient and sustainable" and Goal 15: "Protect, restore and promote sustainable use of terrestrial ecosystems, sustainably manage forests..." are very close to recently adopted federal and regional plans for sustainable development of the Russian Arctic zone (State Program..., 2017; Strategy of social-economic..., 2010, etc.). These programs are aimed at reducing the impacts of economic activities to avoid ecological risks while ensuring economic and social necessities. 
Since the fall of the Soviet Union, many industrial cities and towns of post-Soviet Russia have witnessed large-scale transformation of economy, society etc. connected with the collapse of a whole political system (Tsenkova, 2006). In particular, most of the remote cities, towns and rural regions have suffered from the political and economic transition that brought fundamental changes to these settlements, their people and environment (Heleniak, 2009). Among northern urbanized territories there is a special category of settlements which represents mostly single-industry mining cities and towns. The development of such single-industry cities in the North of Russia is determined by specific economic and social conditions, as well as by natural and climatic factors (Krasovskaya, 2008). The mono-profile character of single-industry cities' economies poses high development risks of the "boom-bust" type and the relevant social problems (Didyk, 2015).

3 When analysing the literature dealing with the period of socialism and post-socialism, K. Stanilov (2007) and N. Kinossian (2017) highlight that the majority of works are primarily focused on the economic and political aspects of the transition. Meanwhile, the situation with the study of potential/options and challenges for further development of post-socialist cities seems to be still inadequate, especially with regard to single-industry cities. Regardless the general trend of growing political interest in the region among Arctic states, peripheral regions in Russia's Arctic specifically remain under-represented in the scientific debates on the future of such remote cities and towns after the fall of socialism (Dale et al., 2018; Heininen et al., 2014; Kinossian, 2017; Wilson Rowe, 2009).

This paper studies the situation of Kirovsk (one of the seven single-industry cities situated in the Murmansk region), which offers an interesting case of transformation in a single-industry town during the post-Soviet time. The case of Kirovsk reflects the situation shared by many industrial post-Soviet cities and towns in the North of Russia, the past and present of which are connected with the resource-oriented economy (Bruno, 2011; Krasovskaya, 2008). More than 300 of such single-industry cities located on the territory of Russia have a total population of about $14 \mathrm{mln}$. Their adaptation to modern economic and social changes meets different challenges highlighting their future controlled by a special Federal priority project "Complex development of monocities" (Passport..., 2016). Like many other northern Russian post-Soviet settlements, the case of Kirovsk provides an example of the industrial peopling of northern areas which had been almost uninhabited before. It shows a typical case of the northern Russian towns which passed through social-economic collapse after the fall of the Soviet Union and then made the first steps towards revival and transition to sustainable development. In order to understand the chances and challenges for a sustainable development and the emerging transformation of post-Soviet singleindustry towns in the North of Russia, the article focuses on the following questions:

5 a) What is the current situation in urban development regarding socio-economic aspects, e.g. what will start / has started after industry fall-down / transformation?

b) What challenges do these towns / cities face today?

c) How do local communities participate in urban planning and development and how do they try to cope with development challenges (civic engagement)?

6 The paper is organised in the following way: the first section introduces the study area, describing the history of the city, its economy, origin, resources and population development for a long-term period (from 1929 till nowadays); the second presents the 
materials and methods of investigation; the third section addresses economic restructuring changes after the transition period ("Perestroika") (1990s), while the final section presents analyses of options which could provide the transition to sustainable development, underlines the strategies for further development, and offers some conclusions.

\section{Study area}

7 Kirovsk is a town in the central part of the Murmansk Oblast, located in a large mining area in the Khibiny Mountains (figure 1), with a population of 27,686 citizens (Mineconomrazvitiya, 2016). Nowadays, together with two urbanized areas-Koashwa and Titan, the town of Kirovsk forms the Kirovsk municipality (Urban Okrug).

Figure 1. Study area.

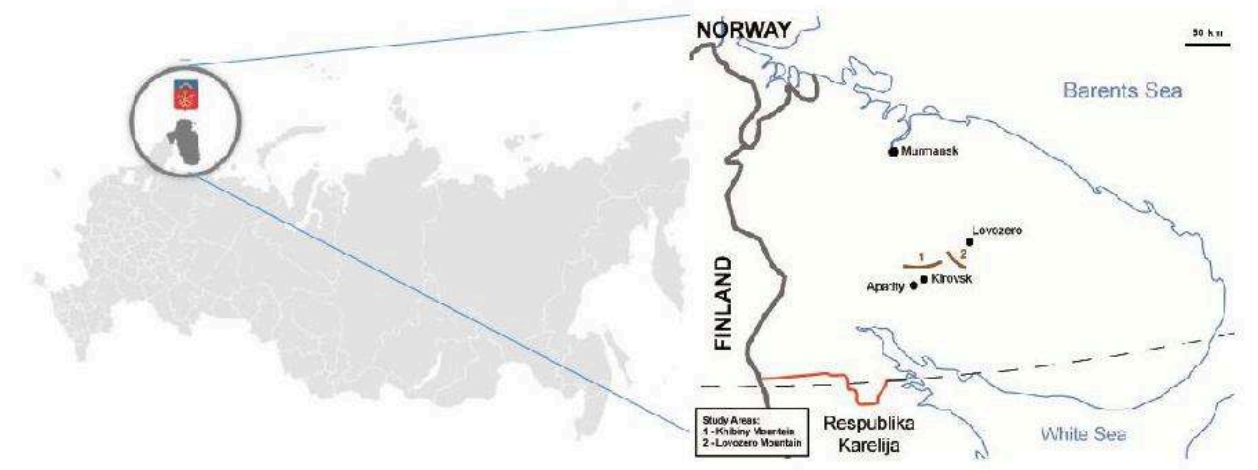

8 Kirovsk was founded in 1929 as Khibinogorsk after the name of Khibiny Montains, and renamed in 1934. The origin of the town is connected with the discovery of apatite ores by the famous Soviet geologist A. Fersman, who named apatite "a stone of soil fertility", because this mineral is rich in phosphorus used for phosphate fertilizers production (Krasovskaya, 2008; Bolotova, Stammler, 2009). The first big apatite deposit, Kukisvumchorr, discovered in 1926 in the Khibiny Mountains, resulted in the process of settlement which started at the end of the 1920s with the first wave of state-induced inmigration to provide labour power, mostly formed by "spetspereselentsy" (former peasants), Gulag prisoners, but also by specialists and contract workers, for extractive industry needs (Wilson Rowe, 2009). The driving force of the industrialization process were passionarias dreaming of their country prosperity (Krasovskaya, 2008). Since the 1950s the second wave of in-migration followed, due to Komsomol members, young specialists in mining and construction inspired by a romantic idea of the North conquerors, as well as by people motivated by higher salaries and promising career prospects (Bolotova, Stammler, 2009). The discovery of apatite ores in the Khibiny Mountains (1920-1926), followed by development of mining and ore-primary processing activities (1929-1935), resulted in a rapid economic development and environmental changes. A new town, Apatity, was established close to Kirovsk in 1935 firstly as miners' settlement and later, in the 1950s, as a platform for a scientific research centre development in the Murmansk Region ("Akademgorodok"). The population of the Apatity-Kirovsk area grew from 10,000-15,000 in 1930 to 23,000 in the summer of 1931 and to 40,000 by the end of 1931 (Kozlov, Barcan, 2000). 
During the post-war restoration and subsequently throughout the Soviet period, Kirovsk alongside with the whole Murmansk region retained its economic specialization. It became a highly urbanized and industrially developed region with predominant raw material sectors development followed by initial transformations of ecosystems (Evseev et al., 2000). The leading sectors present in Kirovsk till nowadays are mining and enrichment (refinery) of apatite and nepheline ores. Considerable efforts were aimed at suburban agriculture development, but after the Transition period followed by economic crises the agricultural sector decreased considerably (Krasovskaya, 2008). $100 \%$ of apatite concentrated in Russia is produced at the "PhosAgro" enterprise (earlier "Apatit" Joint-Stock Company) (Murmanskstat, 2015). Since 2002, "Apatit" has been owned by "PhosAgro" holding - a Russian vertically integrated company and one of the world's leading producers of concentrates for phosphate-based fertilizers. "Apatit" became the town forming State enterprise (Didyk, 2015) (figure 2). Up to 1992 it controlled not only the industrial production, but also almost all urban social spheres. Housing and communal services, retail trade and catering, health care, sport, culture, and most of the social infrastructures before the Transition ("Perestroika") period functioned as subdivisions of the enterprise. In 2003-2004 Kirovsk was included in the list of Russian single-industry towns with the most difficult socio-economic situations (Didyk, Ryabova, 2014).

Figure 2. Contrast views in modern Kirovsk: open-cast mine nearby, the central avenue (left), and apatite-nepheline ore mined in the open-cast mine of Khibiny Mountains.
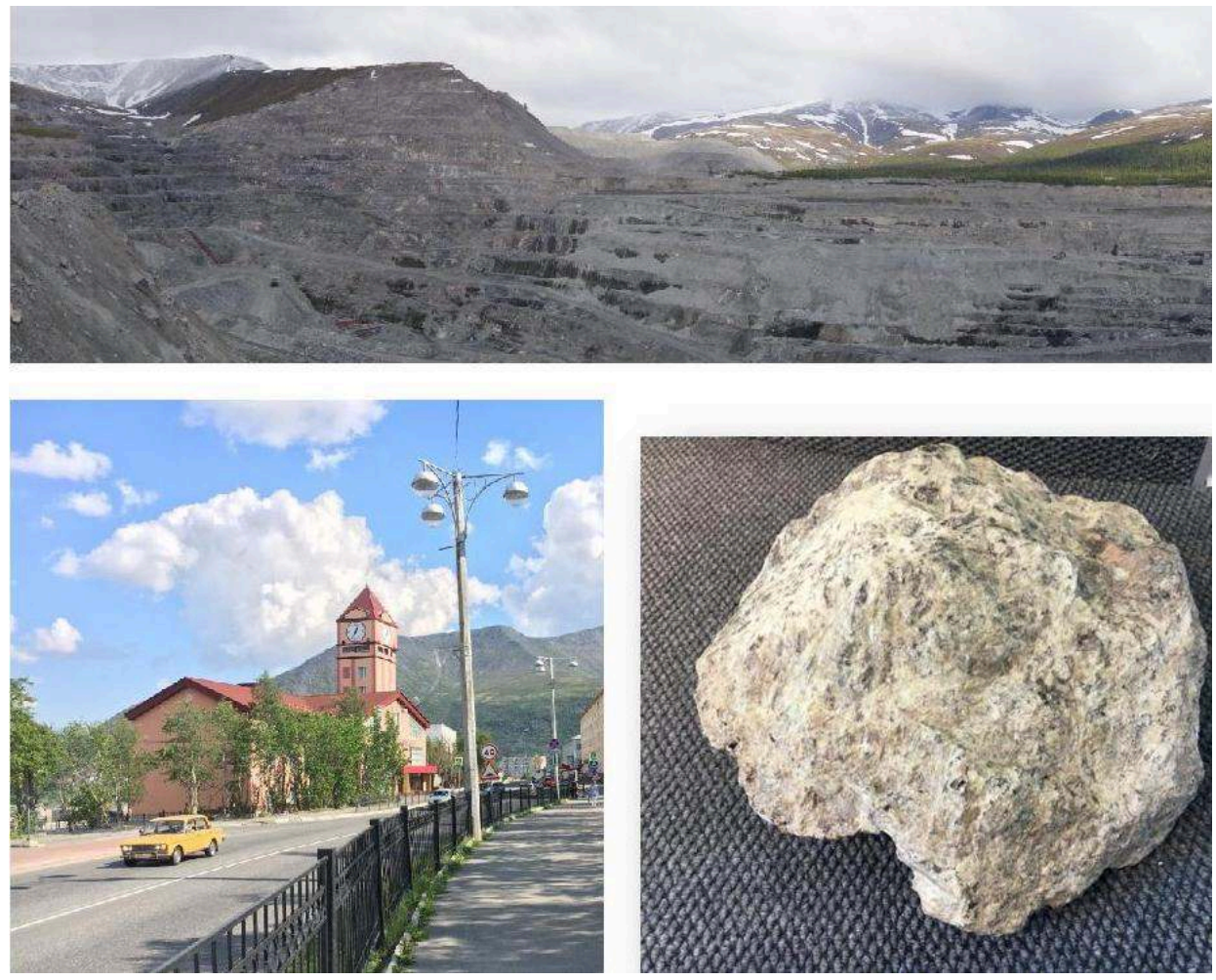

AUTHOR: D. DUSHKOVA 


\section{Materials and methods}

10 The study presented in this paper is based on the data analysis of the Russian federal, regional and municipal documents relevant to the topic. They include social-economic development programs, regional and local policies and plans, census data, regional reports on environment and human health assessments, media coverage. Table 1 shows the final list of planning documents. The most important belong to strategic planning since they provide long-term visions, objectives and measures for the further development of the town of Kirovsk: 2 federal, 1 regional and 7 municipal documents.

Table 1. Planning documents related to sustainable development of Kirovsk.

\begin{tabular}{|c|c|c|c|c|}
\hline Scale & Document & Russian origin title & $\begin{array}{l}\text { Type } \\
\text { (status) }\end{array}$ & $\begin{array}{l}\text { Aspects of } \\
\text { sustainability }\end{array}$ \\
\hline Federal & $\begin{array}{l}\text { State Program } \\
\text { "Social-Economic } \\
\text { Development of } \\
\text { the Arctic Zone of } \\
\text { the Russian } \\
\text { Federation up to } \\
2020 »(2017)\end{array}$ & $\begin{array}{l}\text { ГОСУДАРСТВЕННАЯ ПРОГРАММА } \\
\text { РОССИЙСКОЙ ФЕДЕРАЦИИ " } \\
\text { СОЦИАЛЬНО-ЭКОНОМИЧЕСКОЕ } \\
\text { РАЗВИТИЕ АРКТИЧЕСКОЙ ЗОНЫ } \\
\text { РОССИЙСКОЙ ФЕДЕРАЦИИ" }\end{array}$ & $\begin{array}{l}\text { State } \\
\text { Program }\end{array}$ & $\begin{array}{l}\text { Improvement of } \\
\text { socio-economic } \\
\text { development, } \\
\text { improvement of } \\
\text { quality of life }\end{array}$ \\
\hline Regional & $\begin{array}{l}\text { Strategy of social- } \\
\text { economic } \\
\text { development of } \\
\text { Murmansk Region } \\
\text { till } 2025 \text { (2010) }\end{array}$ & $\begin{array}{lr}\text { СТРАТЕГИЯ } & \text { СОЦИАЛЬНО- } \\
\text { ЭКОНОМИЧЕСКОГО } & \text { РАЗВИТИЯ } \\
\text { МУРМАНСКОЙ ОБЛАСТИ ДО } 2025 \text { Г. } \\
(2010)\end{array}$ & Strategy & $\begin{array}{l}\text { Climate change } \\
\text { and its } \\
\text { consequences } \\
\text { for environment } \\
\text { and human } \\
\text { health, global } \\
\text { scale of } \\
\text { anthropogenic } \\
\text { pollution }\end{array}$ \\
\hline Federal & $\begin{array}{l}\text { Strategy program } \\
\text { on environment } \\
\text { protection in } \\
\text { Arctic zone of } \\
\text { Russian federation, } \\
2009\end{array}$ & $\begin{array}{lr}\text { СТРАТЕГИЧЕСКАЯ } & \text { ПРОГРАММА } \\
\text { ДЕЙСТВИЙ } & \text { ПО } \\
\text { ОКРУЖАЮЩЕЙ } & \text { ОХРАНЕ } \\
\text { АРКТИЧЕСКОЙ ЗОНЫ РФ, } 2009\end{array}$ & $\begin{array}{l}\text { Strategy } \\
\text { program }\end{array}$ & $\begin{array}{l}\text { Identification } \\
\text { and assessment } \\
\text { of } \\
\text { environmental } \\
\text { Hot r spots } \\
\text { (Kirovsk r } \\
\text { among 9 } \\
\text { spots in the } \\
\text { Murmansk } \\
\text { region) }\end{array}$ \\
\hline
\end{tabular}




\begin{tabular}{|c|c|c|c|c|}
\hline Municipal & $\begin{array}{l}\text { Comprehensive } \\
\text { investment plan } \\
\text { for modernizing } \\
\text { the monotown of } \\
\text { Kirovsk, } 2016\end{array}$ & $\begin{array}{lrr}\text { ПЛАН } \quad \text { ПО } & \text { РАЗВИТИЮ } \\
\text { МОДЕРНИЗАЦИИ } & \text { МОНОГОРОДА } \\
\text { КИРОВСК, 2016 } & \end{array}$ & Plan & $\begin{array}{l}\text { Problems and } \\
\text { forecasts of } \\
\text { socio-economic } \\
\text { development, } \\
\text { SWOT analysis, } \\
\text { tourism } \\
\text { development as } \\
\text { diversification } \\
\text { of economy }\end{array}$ \\
\hline Municipal & $\begin{array}{l}\text { Forecast of socio- } \\
\text { economic } \\
\text { development of } \\
\text { the Kirovsk } \\
\text { municipality for } \\
\text { the period of 2015- } \\
2017 \text {. }\end{array}$ & $\begin{array}{lr}\text { ПРОГНОЗ } & \text { СОЦИАЛЬНО- } \\
\text { ЭКОНОМИЧЕСКОГО } & \text { РАЗВИТИЯ } \\
\text { МУНИЦИПАЛЬНОГО } & \text { ОБРАЗОВАНИЯ } \\
\text { ГОРОД КИРОВСК НА } 2015 \text { ГОД И НА } \\
\text { ПЕРИОД ДО 2017 ГОД }\end{array}$ & $\begin{array}{l}\text { Decree of } \\
\text { City } \\
\text { Counsil of } \\
\text { Kirovsk }\end{array}$ & $\begin{array}{l}\text { Improvements } \\
\text { in social sphere, } \\
\text { tourism } \\
\text { development as } \\
\text { diversification } \\
\text { of economy, } \\
\text { environment } \\
\text { activities } \\
\text { (minimization of } \\
\text { pollution and } \\
\text { waste) }\end{array}$ \\
\hline Municipal & $\begin{array}{l}\text { Forecast of socio- } \\
\text { economic } \\
\text { development of } \\
\text { the Kirovsk } \\
\text { municipality for } \\
\text { the period of 2018- } \\
2020\end{array}$ & $\begin{array}{lr}\text { ПРОГНОЗ } & \text { СОЦИАЛЬНО- } \\
\text { ЭКОНОМИЧЕСКОГО } & \text { РАЗВИТИЯ } \\
\text { МУНИЦИПАЛЬНОГО } & \text { ОБРАЗОВАНИЯ } \\
\text { ГОРОД КИРОВСК НА } 2018 \text { ГОД И НА } \\
\text { ПЕРИОД ДО } 2020 \text { ГОД }\end{array}$ & $\begin{array}{l}\text { Decree of } \\
\text { City } \\
\text { Counsil of } \\
\text { Kirovsk }\end{array}$ & $\begin{array}{l}\text { Improvements } \\
\text { in social sphere, } \\
\text { tourism } \\
\text { development as } \\
\text { diversification } \\
\text { of economy } \\
\text { (minimization of } \\
\text { pollution and } \\
\text { waste) }\end{array}$ \\
\hline Federal & $\begin{array}{l}\text { List of mono-towns } \\
\text { with most difficult } \\
\text { socio-economic } \\
\text { situation }\end{array}$ & $\begin{array}{l}\text { ПЕРЕЧЕНЬ МОНОПРОФИЛЬНЫХ } \\
\text { МУНИЦИПАЛЬНЫХ ОБРАЗОВАНИЙ } \\
\text { РОССИЙСКОЙ } \text { ФЕДЕРАЦИИ ( } \\
\text { МОНОГОРОДОВ): РАСПОРЯЖЕНИЕ } \\
\text { ПРАВИТЕЛЬСТВА РФ ОТ } 29 \text { ИЮЛЯ } \\
2014 \text { Г. № 1398-Р }\end{array}$ & $\begin{array}{l}\text { Decree of } \\
\text { Russian } \\
\text { Federation }\end{array}$ & $\begin{array}{l}\text { Categorisation } \\
\text { of mono-towns } \\
\text { and } \\
\text { identification of } \\
\text { socio-economic } \\
\text { problems }\end{array}$ \\
\hline Municipal & $\begin{array}{lr}\text { Nature } & \\
\text { conservation } & \text { in } \\
\text { Kirovsk } & \text { and } \\
\text { adjacent } & \\
\text { territories } & \text { in } \\
2017-2019 & \end{array}$ & $\begin{array}{l}\text { МУНИЦИПАЛЬНАЯ ПРОГРАММЯ “ } \\
\text { ОХРАНА ОКРУЖАЮЩЕЙ СРЕДЫ НА } \\
\text { ТЕРРИТОРИИ МУНИЦИПАЛЬНОГО } \\
\text { ОБРАЗОВАНИЯ ГОРОД КИРОВСК С } \\
\text { ПОДВЕДОМСТВЕННОЙ } \\
\text { ТЕРРИТОРИЕЙ В } 2017 \text { - } 2019 \text { ГОДАХ» }\end{array}$ & $\begin{array}{l}\text { Municipal } \\
\text { program }\end{array}$ & $\begin{array}{l}\text { Economy } \\
\text { greening, nature } \\
\text { conservation, } \\
\text { ecological risks } \\
\text { control, human } \\
\text { health } \\
\text { improvement }\end{array}$ \\
\hline
\end{tabular}




\begin{tabular}{|c|c|c|c|c|}
\hline Municipal & $\begin{array}{l}\text { Special Program } \\
\text { ""The formation of } \\
\text { a safe living } \\
\text { environment and } \\
\text { livelihoods of the } \\
\text { population of the } \\
\text { municipality of the } \\
\text { city of Kirovsk } \\
\text { with subordinate } \\
\text { area in } 2017- \\
2019 \text { " Nr. } 622 \text { from } \\
17.05 .2017\end{array}$ & $\begin{array}{l}\text { «ФОРМИРОВАНИЕ } \\
\text { БЕЗОПАСНОГО ПРЕДЫ } \\
\text { ЖИЗНЕДЕЯТЕЛЬНОСТИ НАСЕЛЕНИЯ } \\
\text { МУНИЦИПАЛЬНОГО ОБРАЗОВАНИЯ } \\
\text { ГОРОД } \quad \text { КИРОВСК } \\
\text { ПОДВЕДОМСТВЕННОЙ } \\
\text { ТЕРРИТОРИЕЙ НА } 2017 \text { - } 2019 \text { ГОДЫ } \\
\text { » } 622 \text { ОТ 17.05.2017 }\end{array}$ & $\begin{array}{l}\text { Municipal } \\
\text { program }\end{array}$ & $\begin{array}{l}\text { Assessment } \\
\text { regarding } \\
\text { hygienic and } \\
\text { environmental } \\
\text { norms for safe } \\
\text { urban living }\end{array}$ \\
\hline Municipal & \begin{tabular}{|lr} 
Program & "An \\
\multicolumn{2}{|l}{ accomplishment of } \\
territory & of \\
municipal & \\
formation & town of \\
Kirovsk & with \\
subordinate & area \\
in the & $2017-2019$ \\
years" & $\mathrm{Nr}$ \\
23.12 .2016 & from \\
23.12 .2016 &
\end{tabular} & $\begin{array}{l}\text { «БЛАГОУСТРОЙСТВО } \\
\text { МУНИРИИПОРЛЬНОГО О ОБРАЗОВАНИЯ } \\
\text { ГОРОД } \quad \text { КИРОВСК } \\
\text { ПОДВЕДОМСТВЕННОЙ } \\
\text { ТЕРРИТОРИЕЙ НА } 2017-2019 \text { ГОДЫ» } \\
1560 \text { ОТ 23.12.2016 }\end{array}$ & $\begin{array}{l}\text { Municipal } \\
\text { program }\end{array}$ & $\begin{array}{l}\text { Development of } \\
\text { urban green } \\
\text { infrastructure }\end{array}$ \\
\hline Municipal & $\begin{array}{lr}\text { Strategy } & \text { of } \\
\text { tourism } & \text { and } \\
\text { recreation } & \\
\text { development } & \\
\text { potential } & \text { of } \\
\text { Kirovsk (2017) } & \end{array}$ & $\begin{array}{l}\text { СТРАТЕГИЯ РАЗВИТИЯ ТУРИСТСКО- } \\
\text { РЕКРЕАЦИОННОГО ПОТЕНЦИАЛА } \\
\text { КИРОВСКА (2017) }\end{array}$ & $\begin{array}{l}\text { Analytical } \\
\text { report }\end{array}$ & $\begin{array}{l}\text { Tourism } \\
\text { development } \\
\text { potential }\end{array}$ \\
\hline
\end{tabular}

Long-term field experiences in different regions of the Kola Peninsula including Kirovsk and adjacent territories enabled to reveal several gaps concerning possible negative environmental and health impacts of the current social situation and industrial development. System analysis was the principle method for this study. The panarchy theory (Gunderson, Holding, 2002) provides some valuable conceptual tools to assist our understanding of how ecosystems and economic activities and institutions interact. It also identifies a variety of practical approaches to restore and conserve ecological sustainability. Management systems must take into account various dynamic features of complicated systems: nature-economy-society and be flexible, adaptive.

In order to answer the research questions, we elaborated the investigation model adopted in this research (figure 3) that reflects all the above-mentioned. We tried to look at the process of sustainable development in Russia from different perspectives, including the political and economic background, the legal situation, existing practices of sustainable development and how environmental information circulated, including civil activities and education on sustainable development. There is a great number of sustainability concepts that can be identified in global and Arctic contexts. As Petrov et al. (2017) stated, Arctic sustainability research deals with "wicked problems" associated 
with non-linear processes, changes and transformations, as well as with uncertainty in drivers and outcomes. Moreover, it is largely problem-focused and, thus, orients itself as addressing "grand challenges", such as climate change, well-being and economic development, and the integration of the western and traditional knowledge systems to aid decision-making, adaptive co-management and governance. Despite the fact that "sustainability" is a major concern in Arctic and the North, the issues of the rapid environmental and social (including political, economic and cultural) changes of the region, the definition of sustainability and how it might be achieved, are still much debated (Fondahl, Wilson, 2017). The modern concept of sustainable development proposes taking into account economic, social and environmental components in ensuring the well-being and further development of current and future generations (Bobylev, Perelet, 2013; Stammel, Cyffka, 2015; UN, 2016). In this regard, key aspects of sustainable development include environmental, social, political and legal and economic issues.

The investigation model also endeavours to answer the following questions: what are the national, regional and local circumstances for a transition to sustainable development in Kirovsk, and what is the best possible way to address key economic, social, political and environmental factors (what are the driving forces and promoting factors of urban sustainable development)? A data analysis of the Russian Federal, regional and municipal documents related to sustainability will reveal the current legal framework conditions, business practices and respective approaches of key stakeholders towards a "green economy" and environmental integrity.

Figure 3. Investigation model.

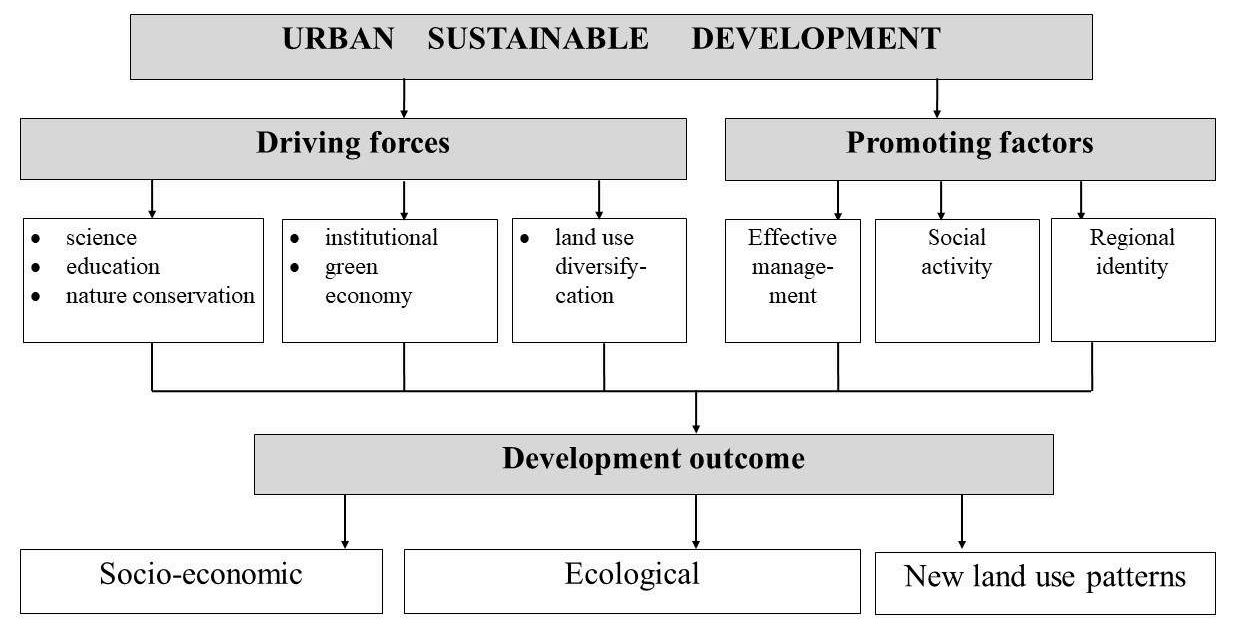

\section{Results and discussion}

Over the last few years the issue of sustainable development has become increasingly important in Russia as reflected in the ongoing reform of environmental legislation in Russia, civil society initiatives and new, greener, business practices (Bobylev, Perelet, 2013; Didyk, 2015; Fondahl, Wilson, 2017). However, the situation in Russia today is still far from perfect. This can mainly be explained by the fact that the statements made by 
top officials usually remain statements; green initiatives developed by civil society groups do not receive state support; new infrastructure projects are developed regardless of ecological aspects, etc. (Bobylev, Perelet, 2013). This is why we find it essential to use a systematic approach to understand the practices and perspectives of sustainable development in Russia, taking into account that the very idea of sustainable development covers many aspects, including economic, ecological and social components. In this section we concentrate on environmental-economic issues by reflecting also the aspects of climate change, ecosystem services concept and issues linked to civil society participation in developing and promoting ideas and practices of sustainable development in the case study region.

In 2016 a Joint list of measures, led by the Ministry of Economic development, was started by the Government (2017) to support single-industry cities. Federal ministries as well as several commercial and non-commercial organizations are responsible for the fulfilment of these measures. The latter, attributed to local differences of singleindustry cities, form 3 main groups:

- promotion of investments in local economy for the development of economic activities different from the existing pattern;

- promotion of private small business and medium-size enterprises for a transition to a sustainable type of municipal development;

- promotion of innovations in business and social infrastructures using modern financial instruments (Passport..., 2016).

Some of these measures are being implemented in Kirovsk nowadays. The most important are aimed at transition to sustainable development, economic restructuring, innovations in industrial technological processes and management, and a new look at future social municipal development. Following the Federal plan for economic development promotion in several territories adopted in 2015 Kirovsk became in 2017 a territory of outstripping economic development (OED) (http:// invest.welcomekirovsk.ru/).

\section{Economic restructuring changes}

17 Like many other Russian enterprises, during the transition period in 1990s "Apatit" experienced deep crises: its production declined up to four-fold, in 1992 one of three ore-processing factories was closed and in the other 2 production activities were reduced (Didyk, 2015; Kozlov, Barcan, 2000). Today "Apatit" makes part of the "PhosAgro" holding and includes five open and underground mines and two processing plants (Murmanskstat, 2015). The situation with employment has changed considerably: if during the Soviet time "Apatit" employed the most part of the town's workforce (11,600 people) and produced more than $90 \%$ of the total town's industrial production, now the company employs less than $30 \%$ (6,400 out of 20,000 of the working age population) (Didyk, Riabova, 2014). Another mining company "NorthWestern Phosphorous Company" (“ACRON" holding), has appeared recently (2005) at the same ore deposits (northern and eastern Khibiny) but its production is much lower, even if accompanying environmental changes are considerable. A part of the "Apatit" miners, attracted by higher salaries, have chosen the new company. A new deeprestructuring program was adopted in 2013 to reduce operational costs and increase labour efficiency in the mining and refinery factories. However, this program has 
dramatic consequences for employees - their number was reduced significantly: from 11,600 in 2012 to 7,100 people at the beginning of 2015 (Didyk, 2015; List, 2013). In 2018 "FosAgro" announced a new ecological program aimed at developing ecology-friendly technologies (www.phosagro.ru). Investments into eco-projects in Kirovsk were $3.3 \mathrm{bln}$ rubles in 2014-2016 (Official portal of the Murmansk region, 2018). After a long period of negotiations between industrial and nature conservation regional sectors in February a new national park, "Khibiny", was created, providing grounds for the development of the recreation sector.

Unemployment growth, dangerous environmental changes connected with the growth of industrial sites and pollution, depletion of rich in phosphorous apatite ores, federal and regional programs for a revival of single-industry cities, nature conservation goals, etc. promoted a rapid development of the tourist sector at the beginning of the $21^{\text {st }}$ century.

19 Currently, Kirovsk is known as a popular mountain skiing resort in Russia and abroad. Good resources and a high potential for the tourist industry development, especially related to winter sports and mountain hiking in summer, are the main options of current sustainable development of the town. Kirovsk is the major skiing center in the northwest of Russia. Tracks of various degrees of complexity have a total length of about $30 \mathrm{~km}$. Six ski-tracks (slalom, giant slalom, super giant and downhill) have certificates of FIS (Murmanskstat, 2015). Tracks for freestyle correspond to international standards. Eight rope tows and a chair lift are organized for tourists on the slopes of Ajkuajvechorr, Rasvumchorr and Kukisvumchorr mountain ridges. One of the key projects planned according to Comprehensive investment plan for modernizing the monotown of Kirovsk (CIP, 2010) was recently completed successfully: a new modern multi-place gondola- and chair-type lifts with the related ski service infrastructure was constructed, and a new mountain skiing resort "Big Wood" at the southern slope of the Khibiny was opened (figure 4). Recently, a new plan aimed at developing recreation and tourist infrastructures was elaborated; Kirovsk will receive new park zones, hotels, transport routes, etc. (CIP, 2010, 2016, 2017; Didyk, 2015, Strategia..., 2017). 
Figure 4. "Big Wood" mountain skiing resort.
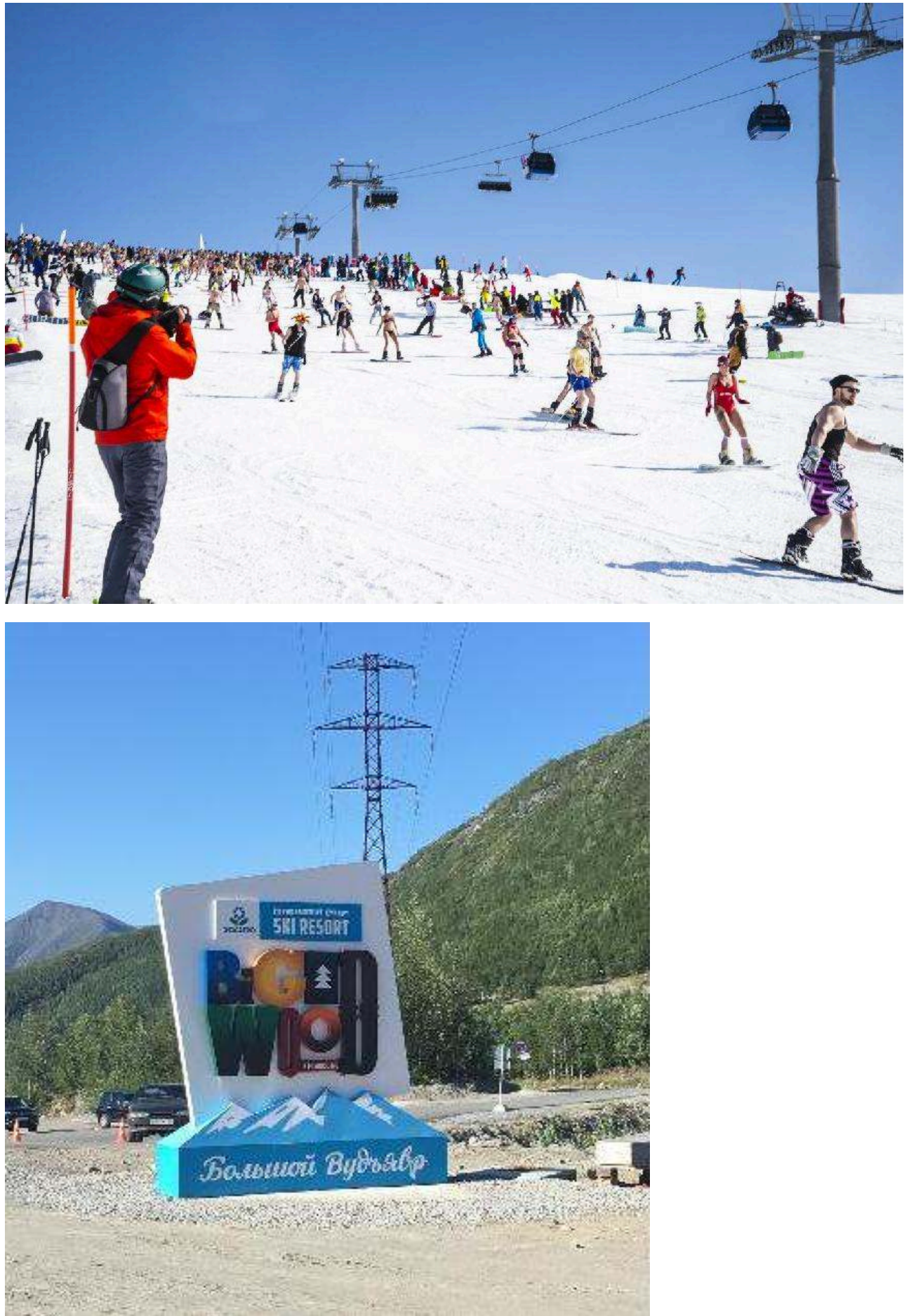

AUTHOR: D. DUSHKOVA

\section{Promotion of small business development}

Within the frame of the Murmansk regional program "Development of economic potential and forming of favorable for business development climate" the first noncommercial regional center "The Khibiny center of Business Development" was 
established in 2015 (http://kirovsk.ru/files/buisness/predpr/sup_SMSP.pdf). "The Khibiny Start" is the name of a small business development program, which was launched by this center in Kirovsk. In the first half of 2016, 65 individual businessmen and 15 small private enterprises mainly in social services were registered in Kirovsk (figure 5). The majority of them received consulting and financial support) (www.Arctic TV https://АРКТИК-ТВ.РФ/news/city/kirovsk/v-kirovske-rabotaet-pervyy-vmurmanskoy-oblasti-nekommercheskiy-centr-razvitiya-biznesa).

Figure 5. Growth of the number of citizens involved into small business (brown column) and number of small private enterprises (blue column).

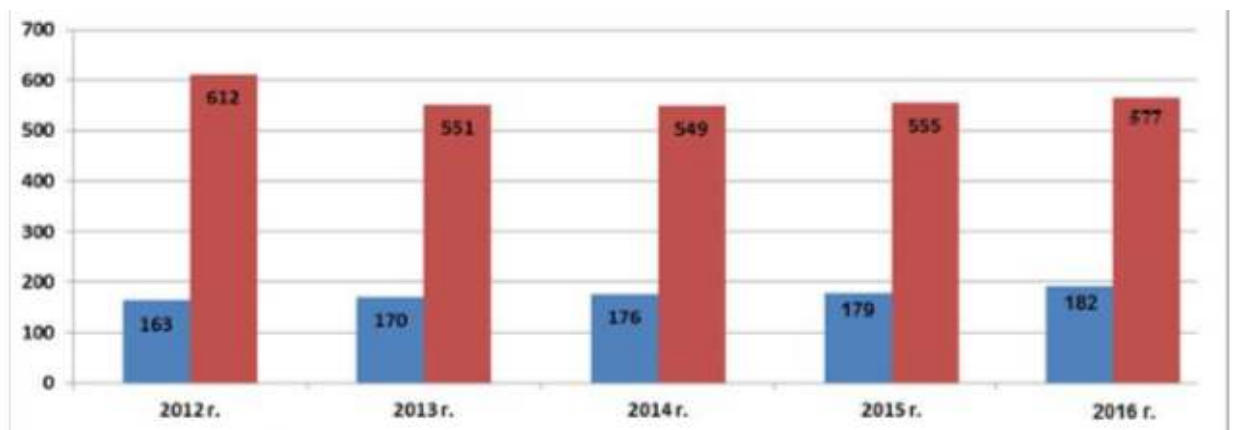

SOURCE: CIP, 2010, 2016, 2017

\section{Promotion of innovations in business and social infrastructure}

A municipal industrial park for innovative technologies in industry and tourism is planned to be established in Kirovsk. It will coordinate small and medium-size innovative enterprises presenting outsourcing departments for the big business (CIP, 2016). As a OSD territory, Kirovsk receives preferences in social-economic development, aimed at promoting external business investments via flexible tax policy, creation of new working places for local population, etc. (CIP, 2017; Tikhonova, 2017).

\section{Options to transit to sustainable development}

There are at least 3 driving forces offering a chance for Kirovsk to move on to sustainable development: social, economic, institutional.

Social driving forces are based on mentality, education and science development. Mentality is connected with innovations and traditions, though many of them are rather contradictive. Market economy promotes individualism opposite to traditional collectivism typical for northern communities supplemented by the traditions of the socialist period. Our experience demonstrates that patriotic feelings are very strong among the senior generation and a part of the medium-aged population (descenders of enthusiasts - "northern conquerors") as well as among children who are taught to love their town at schools and even in the kindergartens via special educational activities (excursions, festivals, clubs, etc.). Municipal authorities via mass media (local broadcasting company and newspapers) inform citizens about the history of Kirovsk and outstanding people who were born there. Annually they arrange folk and sports festivals, promoting local identity development beneficial for civic engagement in innovative practices. 
24 A Technical College, branch of the Murmansk Arctic University since 2016, forms the professional educational status (Murmanskstat, 2015). Geological, ecological, economic, humanitarian departments of the Kola branch of the Russian Academy of sciences (RAS) situated in the town of Apatity are involved in different research activities directed at local sustainable development problems: advanced mining and ore processing technologies elaboration, industrial wastes processing technologies corresponding to economy greening, nature conservation, ecological risks control, human health improvement, etc. The Regional Centre for Occupational Diseases in Kirovsk controls toxic agents' accumulation.

A new plan of green infrastructure is being developed now within the program for tourist industry development (CIP, 2016, 2017). The Botanical garden - Institute belonging to RAS (the Russian Academy of science) situated in Kirovsk, which has contributed largely to greening of the town till now, will be involved into this project as well. The Kola Scientific Centre (Rus. "Akademgorodok") makes successful efforts in conducting research on environmental friendly technologies in mining and processing, environment rehabilitation, economy diversification, etc. (Murmanskstat, 2015).

26 A civic engagement of the local community and public participation in the urban development process both at the stage of planning and realization are beneficial to urban innovative sustainable development. One example is NGOs' activities in Kirovsk to support the Nature Park "Khibiny", opened in February 2018 (figure 6), threatened by the enlargement of mining activities. Municipal mass media are used as an open platform for such discussions.

27 Ecological activities of municipal authorities supported by the Murmansk regional programs are an important driving force promoting transition to sustainable development. A new program for 2017-2019 directed at rubbish pollution control and improvement of sanitary management municipal scheme was adopted in 2016 (Nature conservation..., 2016).

Economic driving forces are connected with the recovery from the economic depression period promoted by the Federal, the Murmansk region and municipal plans. Investments for municipal plans for infrastructure development in the 2016-2020 budget are estimated at 3,308,691.20 th. rubles (CIP, 2016), etc. (see below). Economy diversification support is another important factor promoting transition to sustainable development. The tourist sector appeared to be in the focus of this process. The Complex Investments Development plan for Kirovsk, adopted in 2016, includes different scenarios of economy diversification and touristic activities, paying a special attention to an infrastructure. The first so-called "Anchor" investment projects for tourist infrastructure development - all-seasons Lovchorr and Vud'yavrchorr centers have already been elaborated. They are directed at multiple outdoor recreation activities: hiking, skiing, alpinism.

Institutional driving forces are connected with the development of more independent from FosAgro municipal administrative activities promoted by economic diversification. The Complex Investment Development plan (CIP, 2017) implementation will be managed by a Coordinating Center made up of municipal administration and investors. According to a special agreement between Kirovsk municipal administration and Murmansk regional administration the touristic cluster is included into the regional tourism development program "Russian Lapland". 


\section{Strategies to face the challenges on the way to sustainable development}

\section{Socio-economic challenges}

According to long-term plans of municipal development (Forecast, 2014; CIP, 2016), the mining industry will have the leading role for the future economy of Kirovsk as it was before. Due to the implementation of advanced technologies at "Apatit" and further exhaustion of ore deposits the unemployment rate may increase (CIP, 2016). To meet this challenge plus ecological challenges (see below) long-term plans for city development highlight the transition to a diversified local economy. The development of the tourist industry is planned to receive 100,000 tourists every year (CIP, 2016). Modern touristic infrastructures, the proximity (relevant to Russian territory) to big cities - St.-Petersburg, Petrozavodsk and even Moscow, etc. - and Scandinavian countries, pristine northern nature, northern lights in winter etc. attract tourists to the Kirovsk region. The growing problems of unemployment connected with the policy of the town-forming mining company that is rationalizing its operations and cutting personnel (Didyk, 2015; Didyk, Ryabova, 2014; Fondahl, Wilson, 2017) are in need of economic diversification.

The "Apatit" company is now motivated by requests from different levels of governmental or political bodies and by the international requirements for corporate codes to be responsible for the town and local community. The company has been doing a lot for the towns' improvement, repairing roads and reconstructing social infrastructures - for example, it financed full reconstruction of the lakeside promenade and of the swimming pool in Kirovsk in 2008-2012 and granted 20 million rub. for the renovation of the department of intensive therapy at the city hospital in 2013 (Forecast, 2014; Mineconomrazvitiya, 2016). The company is funding socially important projects ("Problems of our town we resolve together"). Owing to the long-time role of the main-employer enterprise in Kirovsk and regular social activities "Apatit" enjoys a strong trust among the community, and even a psychological identification for a large part of the population (Didyk, Ryabova, 2014), despite some disagreements about environmental aspects.

Since the period of transition in the 1990s, the town of Kirovsk, just like other towns and cities in northern Russia, is experiencing depopulation (Murmanskstat, 2015) (figure 7) due to emigration flows and a high mortality rate. The strategic urban development program (Forecast, 2014) also gives the highest priority to the social sphere.

\section{Ecological and land use challenges}

\section{Ecological problems}

Nowadays Kirovsk faces two main ecological problems: air and water pollution and ecosystems mechanical disturbances and degradation.

Beginning from its origin Kirovsk's industrial development was followed by environmental radical changes, partial or total ecosystems transformation. The industrial complex of "Apatit" contributes to air pollution mainly by dust, nitrogen and carbon oxides, etc. (Dushkova and Evseev, 2011). The mining complex is of vast dimensions, and hence there are large deposits and large areas that have been scarred 
by mining activity, especially severe at the open cast apatite mine near Kirovsk (figure 2) which produces activization of unfavourable processes: landslides, stone falls, earthquakes, avalanches. The total amount of wastes accumulated in the storage facilities of "Apatit" refineries is about $400 \mathrm{mln}$ tons (Krasovskaya, 2008). Mechanical disruptions of soils and ground are found in those territories. In the framework of several research projects it was stated that the real area is however 3-5 times larger than officially reported (Dushkova, Evseev, 2012). The ecological situation in some territories of Kirovsk and surroundings was assessed as "crisis". This leads to an increase in the local population's morbidity and a decrease in life quality. High ecological risks can be proved by congenital development defects (genetic/birth defects), which affect over thirty new-born children in every 1000 in Kirovsk. This value is over six times higher than the Russian mean of 4.8. Various skin diseases can be attributed to high concentrations of polluting agents in the atmosphere. The morbidity level of workers from the processing factories (especially diseases of the osseousmuscular system, silicosis etc.) is distinguished. Heightened death rates from cancer for workers of the processing factories in Kirovsk are also typical (Dushkova, Evseev, 2012). This is connected with some toxic compounds emission during technological processes. To improve the health situation, a Regional Centre for Occupational Diseases was established in Kirovsk in the Soviet time. In addition, different rehabilitation programs initiated by "Apatit" to support the health of its workers during the Soviet era were performed. They are still working at the present time. Nevertheless, the ecological disturbances are still connected with separate territories and beyond them no vivid anthropogenic changes are noticeable. Besides, pollution load is much less compared to other regional industrial centres - Monchegorsk, Nickel, etc.

\section{Necessity for nature conservation}

Unique natural ecosystems presented by northern taiga, forest-tundra and mountain tundra ecosystems and even Arctic deserts at the Khibiny tops surrounding Kirovsk municipality pose favourable conditions for the development of an environmental friendly (in comparison to mining) tourist industry. An important object for environmental protection and tourist industry development is the Khibiny National Park (figure 6).

Figure 6. Khibiny National Park.

Image 1000000000000FC000000BD04749A224.jpg 


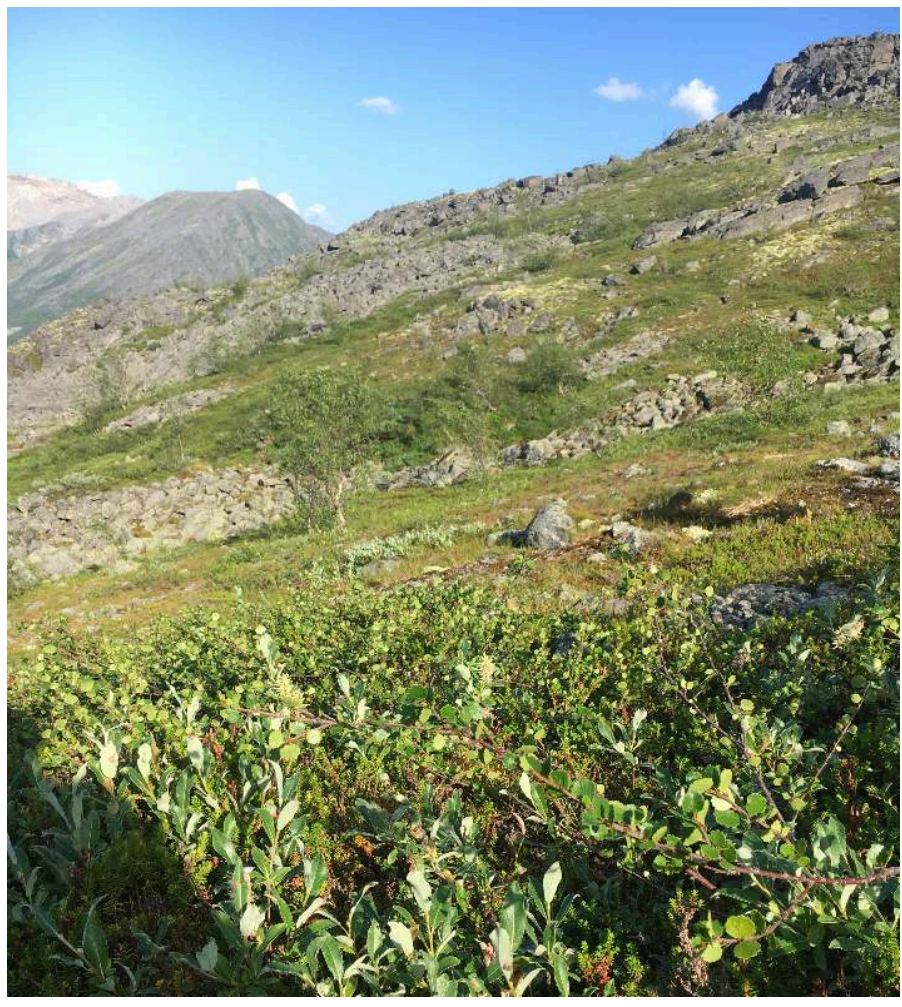

AUTHOR: D. DUSHKOVA

Figure 7. Population dynamic in Kirovsk.

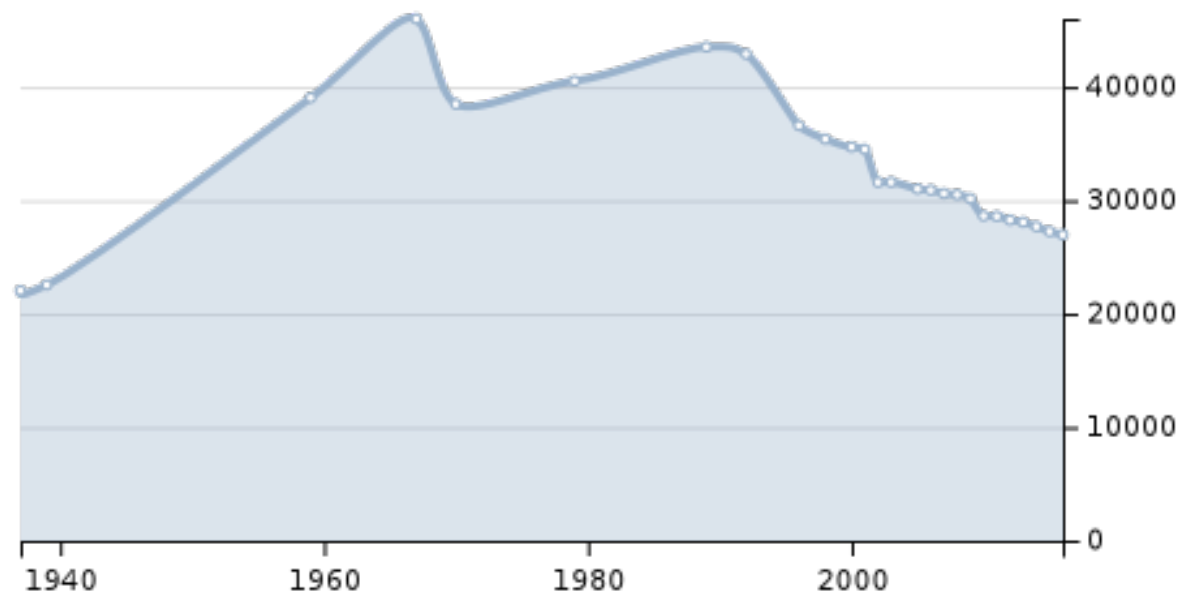

MURMANSKSTAT, 2015-2017

To cope with this challenge, the local community is participating in activities of NGOs to find a compromise combining the interests of mining development, environmental protection and recreation. It may be surprising, however, that some territories beyond the Polar circle with harsh climate conditions and short vegetation period are actively used by their residents not only for recreation but also for agricultural production (potatoes, black currant, green vegetables, etc.). During the overall socio-economic crisis in the late 1990s, the local government started a gradual allocation of a land to employees for allotments (Rus. "dacha") and gardens (Rus. "sadovoe tovarishestvo") in the forested suburbs of Kirovsk (Dale et al., 2018; Kozlov, Barcan, 2000; Krasovskaya, 
2008). Today, inhabitants of Kirovsk continue the active use of these plots (dachas and gardens) as an additional source of income - for growing production for home consumption or informal market sale. For some inhabitants it is a place for summer holiday/vacation, because trips to southern regions are expensive. It must be mentioned in this respect that those who work in subpolar regions, excluding private sector, may receive Federal money support for transport expenditures to get to popular resorts once in 2 years (Krasovskaya, 2008; Didyk, 2015).

Economy diversification is connected with land use pattern changes. No more industry receives priorities in land use. Recreation and nature conservation land use patterns attract the growing attention of local authorities because they may contribute to socialeconomic development for a long period originating from permanent supply of ecosystem services but not from exhaustible mineral resources.

\section{Modern climatic changes and ecological situation}

38 Kirovsk as well as the whole Murmansk region, being one of the northernmost regions of Russia, is highly vulnerable to climate change. Recent climatological data (IPPC, 2014; Kislov et al., 2011; AMAP, 2011; Konstantinov et al., 2015) demonstrate noticeable climate changes in the Arctic zone in general and the European Arctic as well. Climate warming trends will be followed by higher winter temperatures, prolongation of vegetation period, increase in precipitation during the warm period. According to data of Konstantinov et al. (2015), an intensive heat island (up to $3.2^{\circ} \mathrm{C}$ ) has been identified in Kirovsk and Apatity that was based on the underlying surface temperature, and its mean intensity over the observation period significantly exceeds the representative data for European cities in winter. Climate change social response is contradictive: the growth of biological productivity of local ecosystems, which increases their resilience, longer warm period, which may decrease heating length, milder winters, etc. are favorable. At the same time summer precipitation's increase may launch bogging. Summer temperatures rise and growing frequency of anomaly climatic events summer draughts produce a risk of forest fires. Winter heavy snowfalls and sharp rises in air temperatures increase the risk of avalanches. Human health effects of climate change include increased occurrence of weather-related health disturbances as a consequence of weather instability, increased respiratory morbidity, as well as the spread of bacteria and viruses at anomaly temperatures background (Dushkova, Evseev, 2012). Other negative consequences of climate changes are connected with flooding in some Khibiny valleys. Open cast mining, tourism development, "dacha" recreation, etc. are sensitive to climate change.

Scientific research activities of the local RAS department and the international research community have mainly contributed to the study of the challenges caused by climate change in the region. They are aimed at identifying priorities for actions and projects on the reduction of greenhouse gas emissions and adaptation to climate change for the Murmansk region as well as at integrating climate strategies into the programs of socio-economic development for the region. Local environmental NGOs' activities are focused on the involvement of the regional administration and the business community in climate strategy development and realization, and various public information actions. 


\section{Institutional challenges} political, economic and cultural restructuring of post-socialist cities from the western social sciences during the last two decades: Herrschel T. (2007), Stanilov K. (2007), Czepczyński M. (2008), Hirt S. (2015), etc. However, post-socialist urban study still has a great number of question marks and dilemmas to be discussed (Berki, 2014; Bruno, 2016; Tsenkova, 2006). As Nawratek (2012) noted, after the collapse of communism at the end of the $20^{\text {th }}$ century the majority of European socialist industrial cities in Central and Eastern Europe supported two ideas: 1) the idea of neoliberal deregulated management based on private, multi-agent ownership of land (and on land speculation) 
and the weakened role of the city council and 2) the 'mentality turn' rejecting the industrial heritage of the socialist city and focusing on a post-industrial service-based economy mainly - tourism and cultural production. The case of Kirovsk shows that though this town still has strong relation to the period of socialism as its natural resources determine the leading role of industry in the economic development, it is ready to diversify economy via tourism development. The case of Kirovsk confirms the shift in the Russian policy in the north: economy diversifying based on innovative technologies corresponding to green economy pattern with a special concern of life quality. This may be regarded as a positive turn to achieve sustainable development goals. Here, based on the case of Kirovsk analysis, we can follow the argument provided by Bobylev and Perelet (2013) according to which the transition to sustainable development in Russia has become an important aim and this term refers to a high social and ecological "quality" of economic growth, that is pursuing economic growth while ensuring social development and environmental conservation. In this regard Kirovsk as a post-Soviet single-industry town in northern Russia presents a fascinating arena at the crossroads of development ideas supported by scientific research activities of the local RAS department and international research community.

The case of Kirovsk confirms the idea of Berki (2014) that the long-term, relatively slow and gradual processes of urbanization are occasionally interrupted by periods of turbulent restructuring. For a long period, mining activities initiated urban development and shaped the everyday life of citizens, education and health sectors as well as the infrastructure and welfare of the residents. At the same time, industrialization caused negative environmental impact during the whole period of mining and processing. Turbulent reconstruction period demonstrates the shift from an authoritarian type of governance, weak civil society institution etc., which were common for the previous period, to the development of democratic governance with the ability of broad discussions of the future plans, taking into account the interests and preferences of urban dwellers. Ecological and social-economic problems in the focus of public attention present a promoting factor for adoption of mitigating measures.

The history of Kirovsk, its spatial organization and land use, which belong to the different time frames, are likely to set the direction of future urban development. Analysis of various urban transformations in Kirovsk linking the economic development and restructuring and socio-economic reforms highlights driving forces and challenges on the way to sustainable development typical for similar singleindustry towns in the north of Russia. Economy diversifying, implementation of sustainable mining practices initiated by environmental friendly innovative management may help to transit to a new land use pattern and nature management. Moreover, active public participation in the urban development shows the current role of local people not as "victims" but rather as agents of development of the town (Kinossian, 2017; Rautio, Tykkylänen, 2008). Participatory approaches allow to link economy, management and policies interests.

Nowadays, institutional conditions in Russia are characterized by a high level of power centralization, the critical role for achieving sustainability goals at the local level, especially for single-industry municipalities, lies with state support from both federal and regional governments (Didyk, 2015). A special Federal program directed at singleindustry towns revitalization wherever it is possible is underway since 2016. Accepting 
a status of OSD territory Kirovsk receives preferences in economic planning and development. No doubt that in the nearest future such single-industry mining towns as Kirovsk may achieve the sustainable development goals proposed in its strategic program aiming to improve the management of mining in post-socialist cities/ settlements, in order to become a town with favorable socio-economic and environmental situation and supportive health and well-being of its citizens. Moreover, Kirovsk and Russia in whole can play a crucial role in the formation of sustainable development and the new global economy since it has vast natural capital and critically important ecosystem services that contribute to the sustainability of the biosphere and provide economic benefits to all mankind. Its vast areas untouched by economic activity, colossal forests and wetlands, freshwater resources and biodiversity are all major potential contributors to the formation of the new economy in the world.

\section{BIBLIOGRAPHY}

AMAP (2011), Arctic Climate Issues: Changes in Arctic Snow, Water, Ice and Permafrost, overview Report.

BERKI M. (2014), "Return to the road of capitalism: Recapitulating the post-socialist urban transition”, Hungarian Geographical Bulletin 63, 3, pp. 319-334, doi: 10.15201/hungeobull.63.3.6. BOBYLEV S., PERELET R. (eds.) (2013), Sustainable Development in Russia, Berlin-St. Petersburg. BOLOTOVA A., STAMMLER F. (2009), "How the North became home. Attachment to Place among Industrial Migrants in Murmansk region”, in SOUTHCOTT C., HUSKEY L. (eds.), Migration in the Circumpolar North: New Concepts and Patterns, Edmonton, Alberta, Canada, Canadian Circumpolar Institute Press, University of Alberta, pp. 193-220.

CIP (2010), Comprehensive investment plan for modernizing the monotown of Kirovsk and adjacent territories in Murmansk Oblast, http://minec.gov-murman.ru/files/4_3.doc\#_Toc260749594, accessed 03.12.2016 (in Russian).

CIP (2016), Comprehensive investment plan for modernizing the monotown of Kirovsk and adjacent territories in Murmansk Oblast, http://kirovsk.ru/files/npa/adm/2016/0741/post_741_2016_p.pdf, accessed 01.11.2017 (in Russian).

CIP (2017), Comprehensive investment plan for modernizing the monotown of Kirovsk and adjacent territories in Murmansk Oblast, http://minec.gov-murman.ru/documents/kiro.pdf, accessed 21.101.2018 (in Russian).

CZEPCZYŃSKI M. (2008), Cultural Landscapes of Post-Socialist Cities. Representation of Powers and Needs, Farnham, Ashgate.

DALE B., BAY-LARSEN I. \& SKORSTAD B. (2018), The Will to Drill - Mining in Arctic Communites, Springer Polar Sciences.

DIDYK V. (2015), "Development Challenges for a Single-Industry Mining Town in the Russian Arctic: The Case of Kirovsk, Murmansk Region”, Russian Analytical Digest, 172, pp. 2-7.

DIDYK V., RYABOVA L. (2014), “Monogoroda Rossiyskoy Arktiki: strategii razvitiya (na primere Murmanskoy oblasti), [Single-industry towns of the Russian Arctic: Development strategy on the 
case study of towns in the Murmansk region]", Ekonomicheskie i sotsialnyie peremenyi: faktyi, tendentsii, prognoz, 3, pp. 84-99.

DUSHKOVA D., EVSEEV A. (2012), “The Russian North: Environment and Human Health Risk Assessment”, Risk Models and Applications, 7, pp. 89-102.

EVSEEV A.V., BELOUSOVA A.P., IVANOV V.V. et al. (2000), Environmental hot spots and impact zones of the Russian Arctic, Moscow.

FONDAHL G., WILSON G.N. (2017), Northern Sustainabilities: Understanding and Addressing Change in the Circumpolar World, Springer.

(2014), Forecast of socio-economic development of the Kirovsk municipality for the period of 2015-2017, http://kirovsk.ru/files/npa/adm/2014/1417/prognoz_2015_2017.pdf, accessed 10.12.2016 (in Russian).

GUNDERSON L., HOLDING C. (2002), Panarchy. Understanding Transformations in Human and Natural Systems, Washington, Island Press.

HASSAN A.M., LEE H. (2015), "Toward the sustainable development of urban areas: An overview of global trends in trials and policies", Land Use Policy, 48, pp. 199-212, https://doi.org/10.1016/ j.landusepol.2015.04.029.

HEININEN L., SERGUNIN A. \& YAROVOY G. (2014), Russian strategies in the Arctic: Avoiding a new cold war, Moscow, Valdai Discussion Club, http://www.uarctic.org/media/857300/arctic_eng.pdf, accessed 20.10.2017.

HELENIAK T. (2009), "Growth Poles and Ghost Towns in the Russian Far North", in WILSON ROWE E. (ed.), Russia and the North, Ottawa, University of Ottawa Press, pp. 129-164.

HERRSCHEL T. (2007), Global Geographies of Post-socialist Transition, London, Routledge.

HIRT S. (2015), "Planning during Post-socialism", International Encyclopedia of Social and Behavioral Sciences ( $2^{\text {nd }}$ Edition), 18, London, pp. 187-192.

IPPC (2014), Climate Change 2014: Synthesis Report. Contribution of Working Groups I, II and III to the Fifth Assessment Report of the Intergovernmental Panel on Climate Change [Core Writing Team: Pachauri R.K., Meyer L.A. (eds.)], IPCC, Geneva, Switzerland, 151 p.

(2017), Joint list of measures to support single-industry cities formed by the Government, http:// economy.gov.ru/minec/activity/sections/econReg/monitoringmonocity/20160415, accessed 20.09.2017 (in Russian).

KINOSSIAN N. (2017), "Re-colonising the Arctic: The preparation of spatial planning policy in Murmansk Oblast, Russia", Environment and Planning C: Politics and Space, 35, 2, pp. 221-238, https://doi.org/10.1177/0263774X16648331.

KISLOV A., GREBENEZ V., EVSTIGNEEV V., KONOSHEV V. et al. (2011), "Effects of possible climate warming in the 21st century for Northern Eurasia", Vestnik MSU, 5: Geography, 3, pp. 3-8.

KONSTANTINOV P., GRISHCHENKO M. \& VARENTSOV M. (2015), “Mapping urban heat islands of arctic cities using combined data on field measurements and satellite images based on the example of the city of Apatity (Murmansk Oblast) ", Izvestia, Atmospheric and oceanic Physics, 51, 9, pp. 992-998, https://doi.org/10.1134/S000143381509011X.

KOZLOV M., BARCAN V. (2000), "Environmental Contamination in the Central Part of the Kola Peninsula: History, Documentation, and Perception", Ambio, 29, 8, pp. 512-517.

KRASOVSKAYA T.M. (2008), Prirodopol'zovanie Severa Rossii (Nature management in the Russian North), Moscow, LKI (in Russian). 
LIST (2013), List of mono-towns with most difficult socio-economic situation, http:// www.minregion.ru/uploads/attachment/documents/100913/100913_p_1.pdf, accessed 08.09.2016 (in Russian).

MINECONOMRAZVITIYA - THE MINISTRY OF ECONOMIC DEVELOPMENT OF THE MURMANSK REGION (2016), Information on socio-economic situation in the mono-profile settlements of the Murmansk region (Kirovsk), http://minec.govmurman.ru/content/devel_city/sub06/sub03/, accessed 13.09.2016 (in Russian).

MURMANSKSTAT - TERRITORIAL BODY OF THE FEDERAL SERVICE OF STATE STATISTICS IN MURMANSK REGION MUNICIPALITIES OF THE MURMANSK REGION (2015), Statistical yearbook, Murmansk (in Russian).

NAWRATEK K. (2012), "Urban Landscape and the Postsocialist City”, CLCWeb, Comparative Literature and Culture, 14, 3, https://doi.org/10.7771/1481-4374.2044.

OFFICIAL PORTAL OF THE MURMANSK REGION (2017), Nature and ecology of Kola Peninsula, publication from murman.ru, 18/02/2017, accessed 20.11.2017 (in Russian).

Nature conservation in Kirovsk and adjacent territories in 2017-2019, 2016//http://kirovsk.ru/npa/ npa_projects/proj_post_121216_04/(in Russian).

Passport of Priority project "complex development of monocities", 2016// http://static.government.ru/ media/files/ (in Russian).

PETROV A., BURNSILVER S., CHAPIN T. et al. (2017), Arctic Sustainability Research: Agenda 2025. White Paper, https://icarp.iasc.info/images/articles/Themes/

WP_Summary_Sustainability_science_ICARP3_draft1.pdf, accessed 02.03.2018.

RAUTIO V., TYKKYLÄNEN M. (eds.) (2008), Russia's Northern regions on the Edge. Communities, Industries and Population from Murmansk to Magadan, Helsinki, Kikimora Publications.

STAMMEL B., CYFFKA B. (2015), Naturschutz, Darmstadt, Wissenschaftliche Buchgesellschaft.

STANILOV K. (ed.) (2007), The Post-Socialist City. Urban Form and Space Transformations in Central and Eastern Europe after Socialism, Springer.

(2017), State Program, "Social-Economic Development of the Arctic Zone of the Russian Federation up to 2020 (Advanced version)”, http://pravo.gov.ru, (in Russian).

UN (2016), 2030 Agenda for Sustainable Development. 17 Sustainable development goals, http:// www.un.org/sustainabledevelopment/sustainable-development-goals/, accessed 11.08.2017.

(2017), Strategia razvitija turistsko-rekreatcionnogo potential. Analiticheskij otchet [Strategic tourism and recreation development of the Kirovsk City. Analytical report, St.-Petersburg.

(2010), Strategy of social-economic development of Murmansk Region till 2025, http://csr-nw.ru/files/ csr/file_category_169.pdf (in Russian).

TIKHONOVA G.I. (2017), About creation of territories of the advancing social and economic development in single-industry towns of the Murmansk region, http://minec.gov-murman.ru/activities/ devel_city/sub06/7/ (in Russian).

TSENKOVA S. (2006), "The Post-Socialist Urban World”, in TSENKOVA S., NEDOVIC-BUDIC Z. (eds.), The Urban Mosaic of Post-Socialist Europe, Heidelberg, Physica-Verlag, pp. 349-366.

WILSON ROWE E. (2009), Russia and the North, Ottawa, University of Ottawa Press. 


\section{ABSTRACTS}

Development in northern Russian cities is determined by specific economic and social conditions, as well as by natural and climatic factors. Most of these cities were established in the period of the Soviet industrialization and, thus, have a mono-profile character; for that reason, economies of single-industry cities pose high development risks of the "boom-bust" type and the relevant social problems. This paper endeavours to discuss these issues, relying on the case study of Kirovsk (Murmansk region) in order to analyse the urban planning aspects and challenges on the way to sustainability. The main factors (e.g. socio-economic, environmental and land use, institutional) were analysed to learn how they may contribute to sustainable development of Kirovsk as a single-industry town. The role of different stakeholders (mining companies, local communities, and government authorities) in decision making process is discussed. The paper presents the potentials and challenges for a further development of Kirovsk and studies its chances to become a sustainable town. Most challenges are connected with structural and paradigm changes in economy and functionality of enterprises after the collapse of the Soviet Union. Among them are contradictions of interests (e.g. ecological: enterprise owners - citizens), downsizing and depopulation, domestic and foreign market situation, environment pollution and degradation as well as associated health problems linked to the quality of life of the local population. The paper argues that following the long history of industrialization the mining activity is still dominant and has a great influence on the everyday life of urban dwellers. However, Kirovsk also has opportunities to become a sustainable town based on tourism development potential and innovations, development towards environment saving technologies conducted by scientific institutes located there. In addition, participatory approaches (e.g. public participation, involvement of stakeholders and activism of local NGOs) in urban management allow the linkages to be made among specific forms of land use, its management and policies.

Le développement des villes dans le nord de la Russie se heurte à la fois à des conditions socioéconomiques et à des facteurs naturels et climatiques. La plupart d'entre elles datent de la période de l'industrialisation soviétique, ce qui explique leur caractère uniforme. Pour la même raison l'économie de ces villes mono-industrielles présente des risques élevés de cycles "boombust" (expansion /ralentissement) et de problèmes sociaux y afférents. Cet article se base sur une étude de cas menée à Kirovsk (région de Murmansk) visant à analyser l'aménagement urbain et les défis en matière de durabilité. Les principaux facteurs (socio-économiques, environnementaux, institutionnels...) ont fait l'objet d'une analyse, à savoir comment ils peuvent contribuer à un développement durable de Kirovsk en tant que ville mono-industrielle, quel peut être le rôle des différents acteurs (sociétés minières, communautés locales et pouvoirs publics) dans la prise de décision, quels potentiels et défis sont à prendre en compte. La plupart de ceux-ci sont liés à des changements structurels et de paradigme en matière d'économie ainsi qu'à la fonctionnalité des entreprises depuis l'effondrement de l'Union Soviétique, notamment les conflits d'intérêts entre chefs d'entreprises et citoyens, la dépopulation, la situation du marché intérieur et extérieur, la pollution et la dégradation de l'environnement sans compter les problèmes sanitaires liés à la qualité de vie de la population locale. En effet force est de constater que c'est toujours le secteur minier qui domine et il impacte largement le quotidien des habitants. Toutefois, Kirovsk possède certains atouts pour devenir une ville durable grâce à son potentiel touristique, à des innovations et des technologies de préservation de l'environnement développées par les instituts scientifiques locaux. En outre, des approches participatives (public, acteurs locaux, activisme d'ONG) permettent de combiner économie, gestion du territoire et intérêts politiques. 


\section{INDEX}

Keywords: post-Soviet mining city, single-industry town, environment rehabilitation, economy diversification, sustainable development, Kirovsk, Murmansk Oblast, North of Russia Mots-clés: ville minière post-soviétique, ville mono-industrielle, réhabilitation de l'environnement, diversification économique, développement durable, Kirovsk, Région de Murmansk, nord de la Russie

\section{AUTHORS}

\section{DIANA DUSHKOVA}

Faculty of Geography, Lomonosov Moscow State University, Russia, Humboldt University of Berlin, Department of Geography, kodiana@mail.ru, diana.dushkova@geo.hu-berlin.de

\section{TATYANA KRASOVSKAYA}

Lomonosov Moscow State University, Faculty of Geography, Moscow, Russia,

krasovsktex@yandex.ru 